\title{
STRATEGI PROMOSI PERKREDITAN PADA PT BPR INTIDANA
}

\author{
${ }^{1)}$ Endang Suparni, ${ }^{2)}$ Aris Kurniawan \\ ${ }^{1)}$ Dosen Program Studi Sistem Informasi, Universitas Bina Sarana Informatika (UBSI) \\ Jl. Kamal Raya No. 18, Ringroad Barat, Cengkareng, Jakarta Barat \\ Email: endang.esp@bsi.ac.id \\ ${ }^{2)}$ Dosen Program Studi Administrasi Bisnis, Universitas Bina Sarana Informatika (UBSI) \\ Jl. Kamal Raya No. 18, Ringroad Barat, Cengkareng, Jakarta Barat \\ Email: aris.aku@bsi.ac.id
}

\begin{abstract}
Promotion is one of the strategies in the marketing mix in a company, where its function is to introduce and promote products or services to prospective customers or consumers. The purpose of this study was to determine the promotion strategy carried out by PT. BPR Intidana. The type of research is descriptive qualitative which is collecting and processing data and analysis of promotion strategies implemented by PT. BPR Intidana. The technique in collecting data uses interviews and observations, by asking questions directly, the object under study is in accordance with the research. The data source comes from secondary data from various kinds of literature, company documents and so on. In promoting its products, PT.BPR Intidana uses all promotional mixes, namely: advertising through print media, personal selling through marketing personnel, sales promotion by giving gifts, and publicity by sponsoring an activity. Promotion strategies carried out by PT. BPR Intidana is expected to increase the number of customers provided by the credit facility and provide a positive image in the eyes of the public.
\end{abstract}

Keywords: Promotion Credit Sector, Strategy of Company.

\section{ABSTRAK}

Promosi merupakan salah satu strategi dalam bauran pemasaran dalam suatu perusahaan, dimana fungsinya untuk memperkenalkan dan mempromosikan produk atau jasa kepada calon nasabah atau konsumen. Tujuan dari penelitian ini adalah untuk mengetahui strategi promosi yang dilaksanakan oleh PT. BPR Intidana. Jenis penelitian deskriptif kualitatif yaitu mengumpulkan dan mengolah data serta analisis mengenai strategi promosi yang dilakukan PT. BPR Intidana. Adapun teknik dalam pengumpulan data menggunakan wawancara dan observasi, dengan mengajukan pertanyaan secara langsung, objek yang diteliti sesuai dengan penelitian. Sumber data berasal dari data sekunder yang berasal dari berbagai macam literatur, dokumen perusahaan dan sebagainya. Dalam mempromosikan produknya, PT.BPR Intidana menggunakan semua bauran promosi, yaitu: periklanan melalui media cetak, personal selling melalui tenaga pemasaran, promosi penjualan dengan pemberian hadiah, dan publisitas dengan menjadi sponsor dalam suatu kegiatan. Strategi promosi yang dilakukan PT. BPR Intidana diharapkan dapat meningkatnya jumlah nasabah yang diberikan fasilitas kredit tersebut dan juga memberikan citra yang positif dimata masyarakat.

Kata kunci: Promosi Perkreditan, Strategi pada Perusahaan.

\begin{tabular}{llll}
\hline 1. & PENDAHULUAN & & dalam pembangunan dan perekonomian \\
1.1 Latar Belakang & & & suatu negara. Bank diharuskan lebih \\
Perbankan merupakan & salah satu & mengutamakan pelayanan kepada
\end{tabular}
sumber dana bagi masyarakat diantaranya dalam bentuk perkreditan baik masyarakat terutama dalam hal pemberian bagi kredit perorangan maupun badan usaha guna memenuhi kebutuhan konsumen. Perbankan menempati posisi yang strategis kredit. Adapun salah satunya yang lebih dikenal dengan sebutan Bank Perkreditan Rakyat (BPR). Mengingat nasabah sangat memerlukan kredit untuk memulai atau 
mengembangkan sebuah usaha yang produktif dan sangat bermanfaat.

Lembaga perbankan ini juga memberikan fasilitas perkreditan guna meningkatkan usaha untuk kesejahteraan rakyat yang dikelola pemerintah maupun swasta. Bank ini sebagai lembaga keuangan memperoleh laba dengan memberikan berbagai pelayanan jasa kepada masyarakat khususnya kredit. Dalam kehidupan berbangsa dan bernegara, bank BPR memiliki peranan yang sangat besar dalam mendukung aktifitas perekonomian. Hal ini berhubungan dengan fungsi bank sebagai penghimpun dana dari masyarakat guna meningkatkan taraf hidup masyarakat khususnya dalam hal pemberian kredit usaha. Di satu sisi bank juga membutuhkan strategi pemasaran dalam memasarkan produknya. Suatu program manajemen pemasaran salah satunya adalah melakukan strategi promosi yang baik.

Promosi merupakan sarana paling ampuh untuk menarik dan mempertahankan nasabah. Adapun tujuan promosi BPR adalah menginformasikan atau memperkenalkan suatu produk jasa perbankan yang ditawarkan dan berusaha menarik calon nasabah yang baru. Promotional mix merupakan sebuah alat untuk membujuk dan merangsang konsumen ataupun nasabah agar mau membeli atau menggunakan produk atau layanan yang ditawarkan dan juga menciptakan citra perusahaan dibenak masyarakat. Dalam dunia usaha khususnya dalam bidang pemasaran, faktor yang penting untuk membantu dalam usaha mencapai tujuan adalah bagaimana strategi promosi yang dilakukan perusahaan tersebut, terutama pada PT. BPR Intidana salah satu lembaga keuangan perorangan yang juga melakukan berbagai kegiatan melayani kepentingan nasabah dalam menyalurkan kredit bagi mereka yang benar-benar membutuhkan dengan persyaratan tertentu. Dimana lembaga keuangan ini melakukan kegiatan promosi agar produknya dikenal oleh masyarakat luas. Untuk itu peneliti mencoba untuk mengetahui strategi promosi apa saja yang dilakukan oleh PT BPR Intidana agar nasabah tertarik untuk menggunakan produk jasa perbankan dan pelayanan yang diberikan oleh lembaga keuangan tersebut.

\section{TINJAUAN PUSTAKA}

\subsection{Pemasaran}

\subsubsection{Pengertian Pemasaran}

Dalam meningkatkan

omzet penjualan, perusahaan membutuhkan kegiatan pemasaran sebagai penghubung antara perusahaan dan konsumen. Menurut Kotler dan Armstrong (2018:29), bahwa "Marketing as the process by which companies engage customers, build strong customer relationships, and create customer relation ships, and create customer value in order to capture value from customers in return. "Pemasaran adalah aktivitas, serangkaian intuisi, dan proses menciptakan, mengkomunikasikan, menyampaikan, dan mempertukarkan tawaran (offerings) yang bernilai bagi pelanggan, klien, mitra, dan masyarakat umum"

(Tjiptono, 2016:3). Sedangkan menurut Setiyaningrum dkk (2015:1) "pemasaran adalah sebuah subjek yang sangat penting dan dinamis, karena pemasaran menyangkut kegiatan sehari-hari dalam sebuah masyarakat." Jadi dapat disimpulkan, bahwa pemasaran merupakan suatu proses yang terdiri dari kegiatan-kegiatan untuk menciptakan nilai-nilai bagi seluruh pihak yang berkaitan.

\subsubsection{Bauran Pemasaran}

Menurut Malau (2017:10), bauran pemasaran adalah intergrasi perencanaan kegiatan pemasaran melalui 4 (empat) komponen, yaitu produk, harga, promosi 
dan penyalur yang digabungkan bersamasama.

1. Produk.

Produk adalah barang nyata atau tidak nyata yang dapat dijual kepada orang lain. Aspek produk yang diciptakan itu dapat dispesifikasi dengan benda atau jasa

2. Harga.

Mengacu pada jumlah uang yang harus dibayar oleh pembeli agar mendapat produk yang kita jual. Hal ini merupakan proses menetapkan nilai produk dalam bentuk harga moneter.

3. Promosi.

Promosi adalah aspek informasi produk kepada konsumen. Ini termasuk periklanan, promosi penjualan, publisitas, hubungan masyarakat, sponsorship, yang mengacu pada berbagai metode untuk mempromosikan produk, merek, atau perusahaan.

4. Penyalur atau distribusi.

Mengacu pada penyaluran produk agar sampai ke pelanggan. Misalnya, orang yang yang menjual langsung kepada pembeli atau ritel. Penyalur ini kadang-kadang disebut juga tempat jualan, mengacu pada saluran dimana suatu produk atau jasa dapat diperoleh konsumen.

\subsection{Promosi}

\subsubsection{Pengertian Promosi}

Promosi merupakan salah satu cara yang dapat dilakukan oleh perusahaan selain untuk mengkomunikasikan produk, juga untuk menarik calon konsumen agar membeli produk yang ditawarkan, baik berupa barang ataupun jasa. Promosi juga dilakukan perusahaan untuk menawarkan serta menginformasikan produk. Beberapa pendapat yang mengemukakan pengertian promosi. Menurut Gitosudarmo (2014, 159-
160) promosi merupakan kegiatan yang ditujukan untuk mempengaruhi konsumen agar mereka dapat menjadi kenal akan produk yang ditawarkan oleh perusahaan kepada mereka yang kemudian mereka menjadi senang lalu membeli produk tersebut."

Peter dan Olson (2014, 204) menyatakan bahwa "promosi adalah suatu kegiatan yang dilakukan pemasar untuk menyampaikan informasi mengenai produknya dan membujuk konsumen agar mau membelinya". Sedangkan pendapat Hermawan (2012:39) dalam pelaksanaan kegiatan promosi terdapat beberapa hal penting yang harus diperhatikan dalam kegiatan promosi, antara lain; program periklanan yang dijalankan. Kegiatan periklanan merupakan media utama bagi perusahaan untuk menunjang kegiatan promosi dimana promosi memiliki tujuan utama untuk menarik konsumen agar mau melakukan pembelian terhadap produk yang ditawarkan.

Promosi dengan mengutamakan penjualan yang dilakukan secara pribadi lebih dikenal dengan istilah penjualan personal. Kegiatan promosi yang satu ini dapat dikatakan sebagai ujung tombak dari kegiatan promosi. Hal ini karena penjualan personal adalah kegiatan promosi yang mengharuskan pemasar berhadapan dengan konsumen secara langsung.

Berdasarkan definisi-definisi yang telah dikemukakan tersebut, dapat disimpulkan bahwa promosi adalah kegiatan yang dilakukan perusahaan sebagai suatu bentuk usaha perusahaan dalam menginformasikan produknya kepada para konsumen.

\subsubsection{Tujuan Promosi}

Menurut Malau (2017:112) terdapat tujuan utama promosi, antara lain:

1. Menginformasikan (Informing), dapat berupa: menginformasikan pasar 
mengenai keberadaan suatu produk baru.

2. Memperkenalkan cara pemakaian yang baru dari suatu produk.

3. Menyampaikan perubahan harga kepada pasar.

4. Menginformasikan jasa-jasa yang disediakan oleh perusahaan.

5. Meluruskan kesan yang keliru.

6. Mengurangi ketakutan atau kekhawatiran pembeli.

7. Membangun citra perusahaan.

8. Membujuk pelanggan sasaran (persuading) untuk:

a. Membentuk pilihan merek.

b. Mengalihkan pilihan ke merek tertentu.

c. Mengubah persepsi pelanggan terhadap atribut produk.

d. Mendorong pembeli untuk belanja saat itu juga.

e. Mendorong pembeli untuk menerima kunjungan wiraniaga (salesman).

9. Mengingatkan (reminding), dapat terdiri atas:

a. Mengingatkan pembeli/konsumen bahwa produk yang bersangkutan dibutuhkan kan dalam waktu dekat.

b. Mengingatkan pembeli akan tempat-tempat yang menjual produk dari perusahaan tertentu.

c. Membuat pembeli tetap ingat walaupun tidak ada kampenye iklan.

d. Menjaga agar ingatan pertama pembeli jatuh pada produk perusahaan.

Secara singkat promosi berkaitan dengan upaya untuk mengarahkan seseorang agar dapat mengenal produk suatu perusahaan, memahaminya, berubah sikap, menyukai, yakin, dan kemudian akhirnya membeli dan selalu ingat akan produk tersebut.

\subsubsection{Manfaat Promosi}

Menurut Purnama

(2002:151) menyatakan bahwa terdapat manfaat promosi yang berbeda-beda dalam suatu perusahaan, antara lain:

1. Pengenalan Kebutuhan (Need Recognation)

Salah satu tujuan komunikasi, yakni untuk perkenalan produk-produk baru, merangsang munculnya kebutuhan. Pengenalan kebutuhan mungkin juga penting untuk produk-produk yang sudah ada, khususnya bila si pembeli dapat menunda pembeliannya atau memilih untuk tidak melakukan pembelian.

2. Mengumpulkan Informasi (Gathering Information)

Promosi dapat memudahkan seorang calon pembeli mendapatkan informasi. Salah satu tujuan kegiatan promosi produk baru adalah membantu pembeli mempelajari produk tersebut.

\subsection{Bauran Pemasaran}

Dalam menjalankan usahanya, setiap perusahaan tentu memiliki tujuan untuk meningkatkan omzet penjualan, sehingga mendorong perusahaan memperhatikan bauran promosi. Swastha, dkk (2008:349) menyatakan, bahwa “ promotional mix adalah kombinasi strategi yang paling baik dari variabelvariabel periklanan, personal selling, dan alat promosi yang lain, yang semuanya direncanakan untuk mencapai tujuan program penjualan". Menurut Kotler (2008:135) bauran promosi terdiri atas periklanan, penjualan personal, promosi penjualan, hubungan masyarakat, dan pemasaran langsung.

Menurut Lupiyoadi (2014:178) perangkat promosi yang kita kenal mencakup "periklanan (advertising), penjualan perseorangan (personal selling), 
promosi penjualan (sales promotion), hubungan masyarakat (Public Relations), informasi dari mulut ke mulut (word of mouth), pemasaran langsung (direct marketing), dan publikasi pemasaran (marketing publication)".

Menurut Daryanto (2011:94) pada umumnya variabel-variabel yang ada pada promotional mix terdapat 4 (empat), yaitu:

a. Periklanan (Adverstising)

Periklanan merupakan salah satu bentuk kegiatan promosi yang sering dilakukan perusahaan melalui komunikasi non individu dengan sejumlah biaya seperti iklan melalui media masa, perusahaan iklan, lembaga non laba, individu-individu yang membuat poster dan sebagainya.

b. Personal Selling

Personal selling adalah kegiatan promosi yang dilakukan antar individu yang sering bertemu muka yang ditujukan untuk menciptakan, memperbaiki, menguasai atau mempertahankan hubungan pertukaran yang saling menguntungkan kedua belah pihak.

c. Promosi Penjualan

Promosi penjualan adalah salah satu bentuk kegiatan promosi dengan meng- gunakan alat peraga seperti: peragaan, pameran, demonstrasi, hadiah, contoh barang dan sebagainya.

d. Publisitas dan Humas

Publisitas merupakan kegiatan promosi yang hampir sama dengan periklanan, yaitu melalui media masa tetapi informasi yang diberikan tidak dalam bentuk iklan tetapi berupa berita. Berdasarkan bentuk bauran promosi di atas, setiap masing-masing promosi memiliki metode yang berbeda dalam melakukan promosi.

\subsection{Pengertian Kredit}

Pengertian kredit dalam bahasa Latin kredit disebut "credere" yang artinya percaya. Maksudnya pemberi kredit percaya kepada penerima kredit, bahwa kredit yang disalurkan pasti akan dikembalikan sesuai perjanjian. Pada sisi penyaluran dana kredit merupakan pembiayaan yang potensial menghasilkan pendapatan di bandingkan alternative pendapatan lainnya. Sedangkan bagi penerima kredit berarti menerima kepercayaan, sehingga mempunyai kewajiban untuk membayar kembali pinjaman tersebut sesuai dengan jangka waktunya. Oleh karena itu, untuk meyakinkan pihak pemberi kredit bahwa nasabah benar-benar dapat dipercaya, maka sebelum kredit diberikan terlebih dahulu pihak pemberi kredit mengadakan analisis kredit

Menurut UU RI No.7 Tahun 1992 tentang Perbankan Bab 1, Pasal 1, ayat (12) adalah penyediaan uang atau tagihan yang dapat dipersamakan dengan itu berdasarkan persetujuan atau kesepakatan pinjammeminjam antara bank dengan pihak lain yang mewajibkan pihak peminjam untuk melunasi utangnya setelah jangka waktu tertentu dengan jumlah bungan imbalan atau pembagian hasil keuntungan.Kredit adalah semua jenis pinjaman yang harus dibayar kembali bersama bunganya oleh peminjam sesuai dengan perjanjian yang telah disepakati (Hasibuan, 2006:69).

\subsubsection{Unsur-Unsur Kredit}

Adapun unsur-unsur yang terkandung dalam pemberian suatu fasilitas kredit Kasmir (2014:84) adalah sebagai berikut:

1. Kreditur

Kreditur merupakan pihak yang memberikan kredit (pinjaman) kepada pihak lain yang mendapat pinjaman. Pihak tersebut biasa perorangan atau badan usaha. 
Bank yang memberikan kredit kepada pihak peminjam merupakan kreditur.

2. Debitur

Debitur merupakan pihak yang membutuhkan dana, atau pihak yang mendapat pinjaman dari pihak lain.

3. Kepercayaan (Trust)

Kreditur memberikan kepercayaaan kepada pihak yang menerima pinjaman (debitur) bahwa debitur akan memenuhi kewajibannya untuk membayar pinjamannya sesuai dengan jangka waktu tertentu yang diperjanjikan. Bank merupakan pinjaman kepada pihak lain, sama artinya dengan bank memberikan kepercayaan kepada pihak peminjam, bahwa pihak peminjam akan dapat memenuhi kewajibannya.

4. Perjanjian

Perjanjian merupakan suatu kontrak perjanjian atau kesepakatan yang dilakukan antar bank (kreditur) dengan pihak peminjam (debitur).

\subsubsection{Pembiayaan Kredit}

Menurut Kasmir pengertian pembiayaan adalah " penyediaan uang atau tagihan yang dapat dipersamakan dengan itu, berdasarkan persetujuan atau kesepakatan antara bank dengan pihak lain yang mewajibkan pihak yang dibiayai untuk mengembalikan uang atau tagihan tersebut setelah jangka waktu tertentu dengan imbalan atau bagi hasil. Sedangkan menurut Danupranata (2013:103) pengertian "pembiayaan merupakan salah satu tugas pokok bank, yaitu pemberian fasilitas penyediaan dana untuk memenuhi kebutuhan pihak-pihak yang tergolong sebagai pihak yang mengalami kekurangan dana."

Jadi pembiayaan kredit merupakan salah satu jenis pelayanan jasa suatu bank baik bank konvensional ataupun bank syariah yang mana bank memberikan jasa peminjaman uang kepada masyarakat pada bank konvensional atau bank membiayai pembelian sesuatu dalam bentuk pinjaman kepada masyarakat

\section{METODE PENELITIAN}

Dalam penelitian ini mennggunakan metode deskriptif dengan pendekatan kualitatif. Pendekatan deskriptif dilakukan untuk mengidentifikasi dan menjelaskan mengenai objek penelitian. Penelitian kualitatif sering disebut metode penelitian natura listik karena penelitiannya dilakukan pada kondisi yang alamiah (natural setting), data yang terkumpul dan analisisnya lebih bersifat kualitatif. Variabel yang diteliti adalah mengenai promosi. Pengumpulan data dan informasi dilakukan menggunakan observasi, wawancara, dan studi pustaka. Observasi dilakukan dengan cara mengamati secara langsung terhadap objek yang menjadi penelitian penulis. Kemudian wawancara dilakukan secara langsung dengan Manajer Pemasaran PT BPR Intidana. Studi pustaka dilakukan untuk mendapatkan informasi berupa beberapa pendekatan secara teoritis. Teknik pengolahan data dilakukan dengan mengumpulkan data, dan dianalisis secara deskriptif kualitatif.

\section{HASIL DAN PEMBAHASAN}

\subsection{Pembahasan}

Dalam rangka memasarkan suatu produk dan jasa, promosi merupakan langkah yang tepat untuk mewujudkan target pasar yang dikehendaki. Pelaksanaan promosi tanpa didampingi suatu strategi yang tepat tidak akan tercapai target pasar yang maksimal. Adanya kemudahan-kemudahan nasabah dalam prosedur pemberian kredit dan tingkat suku bunga yang murah diharapkan dapat meningkatkan nasabah 
sebanyak-banyaknya khususnya di bidang kredit. BPR Intidana adalah perusahaan yang bergerak dibidang jasa keuangan perbankan yang berdiri atau beroperasi sejak tahun 2002. Dengan didukung oleh kepercayaan masyarakat yang kuat kepada integritas dan sumberdaya perusahaan ini menghasilkan kinerja dan produktivitas tinggi dalam membantu masyarakat ekonomi golongan menengah ke bawah. BPR Intidana mencerminkan dinamika bisnis perbankan yang berpredikat sehat sesuai penilaian Bank Indonesia kepada manajemen.

Kesuksesan BPR Intidana didukung oleh teknologi yang memadai dengan core banking system dari sigma dan peralatan EDC untuk mengotomatisasi transaksi. Segmenpasar yang dilayani saat ini adalah perdagangan, pinjaman kepada pegawai dan wirausaha untuk konsumsi melalui pola potong gaji dengan mitra instansi pembayaran angsuran kredit. Mengingat perusahaan ini andalannya adalah untuk usaha makro kecil dan menengah pada khususnya, sehingga kredit diharapkan benar-benar dapat menjadi modal usaha bagi masyarakat semua golongan, termasuk golongan ekonomi lemah yang membutuhkan dana agar membantu masyarakat dalam usahanya menjadi cepat berkembang. Oleh karena itu BPR ini berupaya untuk memberikan pelayanan yang terbaik, menjadi bank yang terpercaya dan terdepan, memberikan hasil yang baik, dan memperluas jangkauan pelayanan yang tepat sasaran. Dalam rangka meningkatkan kualitas produk dan memberikan rasa aman kepada nasabah, maka seluruh nasabah BPR Intidana telah menjadi peserta program penjaminan simpanan yang diselenggarakan oleh LPS. Selain itu operasional BPR Intidana telah dilengkapi dengan teknologi informasi yang canggih sehingga seluruh BPR dapat memberikan layanan yang baik dan nasabah dapat bertransaksi secara cepat dengan perhitungan yang akurat.

PT BPR Intidana melakukan beberapa strategi promosi, yang termasuk dalam strategi promotional mix. Strategi promosi ini dilakukan untuk mempromosikan produk jasa dan fasilitas kredit yang ditawarkan kepada calon nasabah agar tertarik untuk menjadi nasabah bank tersebut. Berikut ini bentuk kegiatan promosi yang dilakukan PT BPR Intidana, yakni sebagai berikut:

\subsubsection{Periklanan (Advertising)}

Penggunaan strategi promosi dengan iklan dapat dilakukan dengan berbagai media seperti melalui:

a. Pemberian brosur yang berisikan tentang produk dan manfaat produk dan tingkat bunga dari masing-masing produk yang ditawarkan.

Perusahaan menurunkan suku bunga kredit, dengan tetap memperhatikan keuntungan perusahaan, dengan suku bunga kredit dari PT BPR sebagai berikut: kredit umum dengan bunga 1,5\% dari pokok pinjaman dengan klasifikasi nasabah adalah petani, pedagang, usaha makro kecil dan menengah.

b. Pemasangan spanduk ditiap-tiap kantor kas.

Melayani nasabah dengan memperbanyak kantor kas dan pelayanan yang efisien $\quad \mathrm{di}$ tiap-tiap kantor kas. Dalam hal ini para nasabah yang terdapat di daerah-daerah, agar tidak perlu jauhjauh pergi ke kantor PT. BPR Intidana untuk meminjam modal, tetapi dapat langsung dilayani pada kantor kas.

c. Pembagian pamflet. 


\subsubsection{Promosi Penjualan (Sales Promotion)}

Merupakan promosi yang digunakan PT BPR Intidana untuk meningkatkan jumlah nasabah melalui pemberian hadiah kepada nasabah. Setiap tahun PT BPR Intidana mengadakan pengundian berhadiah untuk semua produknya tabungan dan kredit. Untuk produk tabungan, pengundian hadiah berdasarkan nasabah yang aktif menabung di PT BPR Intidana. Sedangkan untuk kredit, pengundian hadiah berdasar- kan nasabah yang melunasi pinjaman sebelum jatuh tempo. Setiap tahun BPR ini mengadakan pengundian berhadiah, antara lain: sepeda motor, handphone, televisi dan hadiah menarik lainnya. Adapun tujuan pengundian berhadiah ini adalah untuk menarik calon nasabah menggunakan produk-produk dan fasilitas kredit dari BPR Intidana.

\subsubsection{Publisitas (Publicity)}

Dengan kegiatan promosi melalui publisitas yang dilakukan PT. BPR Intidana untuk meningkatkan citra bank ini dimata calon nasabah melalui kegiatan sponsorship yang bertujuan agar nasabah mengenal lebih dekat adanya PT. BPR Intidana. Pemberian sumbangan-sumbangan sponsor atas kegiatan-kegiatan yang dilakukan oleh pemuda-pemudi diadakan sekitar wilayah PT. BPR, seperti Tournamenttournament antar kota, seperti : sepak bola, voly, futsall, dan sebagainya.

\subsubsection{Penjualan Pribadi (Personal Selling)}

Personal selling yaitu penjualan pribadi, dengan staff pemasaran terjun langsung ke masyarakat untuk menawarkan kredit dengan menyebarkan brosur dan menyampaikan informasi langsung ke calon nasabah. Merupakan promosi yang dilakukan oleh PT. BPR Intidana melalui pribadi-pribadi karyawan bank tersebut terutama bagian pemasaran di dalam melayani kepentingan nasabah agar nasabah tersebut memanfaatkan produk dan fasilitas kredit. Hal itu dilakukan agar nasabah merasakan kepuasan dan nyaman. Pelayanan kepada nasabah juga dilakukan dengan menjalin hubungan yang akrab dengan para nasabah sehingga mereka merasa satu keluarga.

Pelayanan lainnya juga dilakukan dengan cara melakukan jemput bola. Adapun metode ini merupakan metode unggulan dari BPR Intidana dengan cara nasabah yang ingin isi formulir ataupun yang tidak bisa membayar kewajiban kreditnya ke BPR Intidana dikarenakan adanya kendalakendala atau halangan. Staff pemasar perusahaan akan mendatangi kerumah nasabah. Para nasabah akan merasa puas jika pelayanan yang diberikan para personil BPR Intidana adalah pelayanan yang memuaskan. Pelayanan tersebut dapat diberikan dengan cara bersikap ramah kepada nasabah. Hubungan tersebut dapat diwujudkan dengan cara berkomunikasi dan hubungan relationship dengan nasabah.

\subsection{HASIL}

Dalam memasarkan produknya kepada masyarakat secara luas, PT BPR Intidana menggunakan beberapa saluran promosi baik secara langsung maupun tidak langsung. Saluran promosi secara langsung yang digunakan antara lain: penjualan perseorangan atau yang biasa disebut personal selling atau mouth to mouth. Sedangkan pemasaran tidak langsung biasanya menggunakan promosi penjualan (sales promotion) dan media periklanan, seperti brosur, banner, spanduk depan kantor, dan sebagainya. Dalam usaha periklanan PT. BPR Intidana untuk memasarkan produk jasa perbankan, yakni dengan membagikan brosur-brosur tentang 
kegunaan dan ciri khas dari suatu produk, dan juga diperlihatkan tentang tingkat suku bunga dari masing-masing produk yang ditawarkan serta memberikan hadiah melalui undian-undian yang dilakukan dalam satu kali dalam satu tahun.

Dengan kegiatan periklanan akan memberikan informasi yang seluas-luasnya kepada nasabah mengenai produk jasa layanan perbankan yang ditawarkan. Selain itu dapat lebih mudah dipahami oleh calon nasabah. Oleh karena itu kegiatan periklanan dilakukan lebih giat lagi agar dapat meningkatkan jumlah calon nasabah yang ingin memanfaatkan produk dan fasilitas yang diberikan oleh BPR Intidana. Dalam melakukan program periklanan perusahaan ini mempunyai strategi tersendiri agar promosi melalui iklan dapat berjalan efektif. Periklanan yang bersifat meyakinkan calon nasabah sangat penting dalam persaingan yang semakin ketat sehingga mampu merebut minat dan perhatian calon nasabah.

Untuk promosi penjualan (sales promotion), pihak PT. BPR Intidana memberikan pengundian berhadiah untuk semua produknya. Pihak manajemen PT. BPR Intidana juga menggunakan publisitas dalam usaha promosinya, yaitu dengan melaksanakan kegiatan pameran, kegiatan sosial, bakti sosial dan sponsorship kegiatan. PT BPR Intidana mengadakan pemberian sumbangan-sumbangan sponsor atas kegiatan- kegiatan yang dilakukan oleh pemuda-pemudi diadakan sekitar wilayah perusahaan, melakukan tournamen antar wilayah seperti : permainan futsall, voly, dan sebagainya. Sedangkan untuk personal selling melalui tenaga pemasar, PT BPR Intidana memberikan pelayanan terbaik bagi nasabahnya agar nasabah merasa nyaman dan puas terhadap fasilitas kredit yang diberikan. Selain itu pula guna mempermudah administrasi pelayanan kredit, meningkatkan administrasi pelayanan, semaksimal mungkin PT. BPR Intidana mempermudah pengisian formulir permohonan kredit kepada nasabah dan membantu dalam pengisiannya. Begitupun dalam jumlah pinjaman kredit yang besar menjadikan masyarakat tertarik untuk mengajukan kredit di PT. BPR Intidana.

Mengingat masih adanya peluang bagi perusahaan untuk bersaing dengan BPR maupun bank umum lain, maka perlu dilakukan promosi terus menerus untuk menarik minat nasabah agar menggunakan produk dan jasa yang dikeluarkan oleh lembaga keuangan ini. Untuk itu PT. BPR Intidana melakukan berbagai usaha untuk mengatasi hambatan yang muncul di dalam pelaksanaan strategi promosinya. Usaha-usaha yang dapat dilakukan perusahaan dengan meningkatkan pelayanan, yakni mengadakan pelatihan terhadap karyawan baru maupun lama, meningkatkan fasilitas produk lainnya pada PT. BPR Intidana selain kredit dan tabungan, yaitu deposito, sedangkan untuk mengatasi persaingan antar lembaga keuangan atau bank, PT. BPR Intidana berusaha mencari daerah baru dan menawarkan produk lebih gencar lagi.

Dengan menggunakan media promosi, perusahaan mengharapkan kredit yang disalurkan kepada masyarakat lebih dapat ditingkatkan. Hal ini membuktikan, bahwa nasabah memberikan kepercayaan kepada PT. BPR Intidana untuk melakukan pinjaman dana. Adapun berbagai macam strategi promosi yang dilakukan PT. BPR Intidana untuk meningkatkan citra perusahaan melalui produk kredit maupun tabungan, dan juga meningkatkan kepuasan nasabah, apalagi dengan bunga yang ditawarkan lebih kompetitif. Dengan meningkatkan promosi produk melalui iklan di media cetak dimana memberikan syarat 
perkreditan yang lebih mudah sehingga masyarakat dapat serta merta melakukan peminjaman. Oleh karena itu promosi harus dilakukan secara optimal, terutama para personil pemasaran untuk selalu aktif mempromosikan produk dan pelayanan dari PT. BPR Intidana, mengingat saat ini semakin banyak pesaing yang menawarkan produk yang serupa.

Menjalin hubungan yang akrab dengan para nasabah, merupakan salah satu bentuk pelayanan yang dilakukan oleh petugas pemasaran sehingga mereka merasa satu keluarga dengan perusahaan. Hubungan tersebut biasanya dilakukan dengan cara berkomunikasi dengan nasabah. Hal itu dilakukan agar nasabah merasa nyaman dan puas terhadap pelayanan yang diiberikan oleh PT BPR Intidana. Selain itu pula perusahaan harus memperhatikan jadwal periklanan yang dilakukan selama satu tahun, dan juga memilih media iklan yang paling efektif untuk dilakukan promosi. Adapun tujuan dari PT. BPR Intidana di dalam melakukan aktivitas promosinya adalah mendorong banyaknya nasabah yang akan melakukan peminjaman (kredit) dan juga menabung. Mengingat kegiatan promosi merupakan aktivitas yang sangat penting bagi perusahaan ini di dalam memasarkan produk-produknya. Mengingat banyaknya pesaing dari usaha sejenis, oleh karena kegiatan promosi harus dapat mempengaruhi calon nasabah untuk melakukan peminjaman dana. Dengan ada nya promosi tersebut diharapkan terjadinya transaksi nasabah dengan pihak BPR Intidana.

\section{KESIMPULAN DAN SARAN}

\subsection{Kesimpulan}

1. Strategi promosi produk, terutama produk layanan kredit yang diterapkan oleh manajemen PT. BPR Intidana sudah cukup baik, dan secara umum sudah cukup mencapai tujuan pemasaran.

2. Strategi promosi yang dilakukan BPR Intidana dalam usaha peningkatan nasabah dan kredit yang diberikan, dengan menggunakan promotional mix, yaitu:

a. Periklanan, yaitu dengan berbagai media seperti pemasangan spanduk, pemberian brosur, pemasangan iklan dan pembagian pamflet.

b. Promosi penjualan, yaitu dengan mengadakan pengundian berhadiah untuk produk-produk PT. BPR Intidana, tabungan dan kredit.

c. Publisitas, yaitu PT. BPR Intidana meminjami modal pada para pengusaha ekonomi menengah ke bawah dengan tujuan meningkatkan citra dimata para nasabah.

d. Penjualan pribadi, yaitu dengan memberikan pelayanan terbaik kepada nasabah agar nasabah merasa puas dan nyaman.

3. Usaha-usaha yang dilakukan PT. BPR Intidana khususnya dalam mempromosikan fasilitas kreditnya adalah dengan melakukan antara lain:

a. Menurunkan suku bunga kredit

b. Mempermudah administrasi pelayanan kredit

c. Menjalin hubungan yang akrab dengan para nasabah sehingga mereka merasa satu keluarga dengan bank.

d. Memperbanyak kantor kas dan pelayanan yang efisien di tiaptiap kantor kas. 
\begin{tabular}{ll}
\hline \hline 5.2 & Saran \\
& Setelah mengetahui gambaran strategi
\end{tabular} promosi perkreditan yang telah diuraikan sebelumnya, maka saran yang diberikan oleh penulis yang dapat memberikan manfaat untuk peningkatan strategi promosi perkreditan pada PT. BPR Intidana adalah sebagai berikut:

1. Perusahaan harus dapat mempertahankan dan meningkatkan strategi promosi yang telah dilakukan, meningkatkan kualitas pelayanan terhadap nasabah atau calon debitur, seperti; melakukan jemput bola, selektif dalam memilih calon debitur, dengan penilaian yang lebih mempertimbangkan kelayakan kredit agar tidak terjadi kredit macet.

2. Marketing memberikan penyuluhan kepada masyarakat atau calon nasabah, dengan begitu pengetahuan masyarakat tentang BPR dapat meningkat, sehingga keberadaan BPR tidak asing lagi ditengah masyarakat, dan kepercayaan masyarakat atau calon nasabah bisa bertambah.

3. Untuk meningkatkan, memajukan dan mengembangkan kinerja PT. BPR Intidana, harus diimbangi dengan strategi dan langkah-langkah yang tepat dan nyata, yaitu dengan peningkatan strategi promosi, perbaikan pelayanan dan lainlain. Adanya persaingan antar bank merupakan tantangan bagi PT BPR Intidana untuk terus meningkatkan promosi serta mendorong para karyawan untuk melakukan penanganan kegiatan promosi yang lebih efektif dan efisien.

4. Keterbatasan tenaga pemasar yang dimiliki oleh PT. BPR Intidana karena selama ini tenaga pemasaran atau marketing bukan hanya menangani masalah-masalah pemasaran saja tetapi mempunyai tugas rangkap untuk mengerjakan pekerjaan-pekerjaan lainnya.

5. Promosi yang dilakukan hanya kepada nasabah yang datang ke perusahaan, dan baru sebagian kecil produk bank yang diketahui oleh calon nasabah.

\section{DAFTAR PUSTAKA}

Danupranata, Gita. 2013. Buku Ajar Manajemen Perbankan Syariah, Jakarta: Salemba Empat.

Daryanto. 2011. Manajemen Pemasaran. Bandung: Satu Nusa.

Gitosudarmo, Indiryo. 2014. Manajemen Pemasaran. Cetakan ketiga, Edisi kedua. Yogyakarta: BPFE.

Hasibuan, Malayu SP 2006. Dasar-Dasar Perbankan. Jakarta: Bumi Aksara.

Hermawan, Agus, 2012. Komunikasi Pemasaran. Jakarta: Erlangga.

Kasmir. 2013. Analisis Laporan Keuangan. Rajawali Pers: Jakarta.

Kasmir. 2014. Bank dan Lembaga Keuangan Lainnya. Edisi Revisi, Cetakan Keempat Belas. Jakarta: PT. Raja Grafindo Persada.

Kotler, Philip. 2008. Manajemen Pemasaran Edisi 12 Jilid 2. Jakarta: Indeks.

Kotler, Philip dan Gary Amstrong. 2018. Principles of Marketing. Edisi 15 Global Edition. Pearson.

Lupiyoadi, Rambat. 2014. Manajemen Pemasaran Jasa. Edisi 3. Jakarta: Salemba Empat.

Malau, Herman. 2017. Manajemen Pemasaran: Teori dan Aplikasi Pemasaran Era Tradisional Sampai Era Modernisasi Global. Bandung: Alfabeta.

Peter, J. Paul dan Olson, J.C. 2014. Perilaku Konsumen dan Strategi Pemasaran. Jakarta: Salemba Empat. 
Economicus, Vol. 14 No. 1 - Juni 2020

Purnama, Lingga. 2002. Strategic

Marketing Plan. Jakarta: Gramedia

Pustaka Utama.

Setiyaningrum, Ari, dkk. 2015.

Prinsip- Prinsip Pemasaran.

Yogyakarta: Penerbit ANDI

Swasta, Basu, Dharmesta dan Irawan.

2008. Manajemen Pemasaran

Modern, Yogyakarta: Liberty.

Tjiptono, Fandi. 2016. Pemasaran Esesi

dan Aplikasi. Yogyakarta Andi

Offset.

Sumber Lain:

Company Profil PT BPR Intidana.

UU RI No.7 Tahun 1992 tentang

Perbankan. 